\title{
Increasing Agricultural Complexity: An Approach for Integration of Trees in Cropped Landscapes
}

\author{
M.E. Isaac ${ }^{1, *}$, A.A. Kimaro ${ }^{2}$, Y. Teng ${ }^{3}$ and V.R. Timmer ${ }^{4}$ \\ ${ }^{I}$ Department of Physical and Environmental Sciences, University of Toronto, 1265 Military Trail, Toronto, Ontario, \\ MIC 1A4, Canada \\ ${ }^{2}$ Department of Soil Science, University of Saskatchewan, Canada \\ ${ }^{3}$ Geoscience Department, University of Nevada, USA \\ ${ }^{4}$ Faculty of Forestry, University of Toronto, Canada
}

\begin{abstract}
Temperate agricultural practices that lower external inputs, increase potential for carbon (C) storage, and augment system resilience, particularly through agrodiversity, remain crucial to productive landscapes. Agroforestry systems, the combination of trees and crops, achieve such shifts in agricultural management, predominantly when positive interspecific interactions are optimized. Although early growth competition between tree-crop systems has been well documented, little work has developed effective techniques to minimize residual antagonism with agroforestry systems. To mitigate such competition, we used a model tree-crop system to test the effectiveness of nutrient spiking the tree component [Pinus strobus L. (white pine)] on reducing belowground competition with the crop component [Zea mays $\mathrm{L}$. (corn)]. Nutrient spiking is widely used in monoculture plantation systems, but no work has redirected this technique to multispecies agroforestry systems. We hypothesized that the internal accumulation and retention of nutrients associated with nutrient spiked pine seedlings will lower stress on native soil resources after out-planting, permitting increased nutrient availability for crop growth. Two levels of nutrient spiking [untreated (S0) and spiked (S1)] of white pine were intercropped with corn, as well as monoculture controls for each species, under greenhouse conditions. After 2 months, root biomass response of corn and pine was significantly higher (19\% and 52\% respectively as compared to monoculture growth) in the nutrient spiking treatment. Nutritionally, nitrogen $(\mathrm{N})$, phosphorus $(\mathrm{P})$ and potassium $(\mathrm{K})$ significantly increased in pine tissue with pre-transplant spiking. This presumably reduced stress on native soil nutrients and resulted in the steady or increased $\mathrm{N}, \mathrm{P}$, and $\mathrm{K}$ uptake in corn shoot tissue (increases of 19\%, 0\%, 49\% respectively) intercropped with spiked pine in comparison to corn in monoculture. Our findings contribute a preliminary examination of pretransplant nutrient spiking practices to reduce resource stress and mitigate nutritional competition during early crop growth in an agroforestry context. Such specialized practices may be useful in order to promote integration of trees in cropped landscapes for the eventual benefits of nutrient and hydrological regulation as well as increased productivity and C storage capacity.
\end{abstract}

Keywords: Agroforestry, Biomass, fertilizer use, intercropping, nutrient competition, Southern Ontario, vector analysis.

\section{INTRODUCTION}

Temperate agricultural practices that lower external inputs, increase potential for carbon storage, and augment system resilience through diversification remain crucial to landscape sustainability. Agroforestry, the integration of trees on the cropped landscape, may prove an essential practice to achieve such shifts in agricultural management when positive interspecific interactions are optimized. Furthermore, to reduce agrarian vulnerability to climate change, the inclusion of trees within agricultural production systems can mitigate risk through hydrological regulation and reduced severity of harsh weather events. However, this requires not only an accurate understanding of species interactions for optimal

*Address correspondence to this author at the Department of Physical and Environmental Sciences, University of Toronto, 1265 Military Trail, Toronto, Ontario, M1C 1A4, Canada; Tel: 416-287-7276; Fax: 416-287-7279; E-mail: marney.isaac@utoronto.ca productivity and the quantification of biophysical effects of trees in agricultural landscape, but also the development of new techniques to promote such agroforestry practices, specifically in a temperate regional context.

The beneficial functions found in agroforestry systems, such as improved nutrient cycles, often occur later in farm maturation [1-3], suggesting that farm establishment is a crucial stage for securing complementarity between species. In mature systems, stratified rooting zones may develop providing spatial separation and reducing competition. Trees and crops differ enough morphologically that stratification of above and belowground biomass may lead to differentiation of resource utilization zones [4, 5]. However, on nutrient deficient sites and during the early growth phase of intercropping, tree roots may out compete growing crops for belowground resources $[6,7]$, particularly as root size asymmetry may not yet be present in an agroforestry system. 
Although crop establishment is usually initiated from seed, the tree component in a temperate agroforestry system may originate from reared seedlings in nurseries. Previous work has found that, often, seedling substrate is insufficient to supply nutrients after out-planting [8]. This is observed as nutritional dilution in plant tissues as well as a reduction in electrical conductivity (ECe) in the associated substrate, indicating low ion concentration. Seedling root plugs offer a useful resource for nutrient supply as peat substrate can reach high cation exchange capacity levels and are crucial to support growth after planting [9-12], particularly at sites with low soil fertility [13]. Therefore, in the absence of infield fertilization, an effective method to offset competition during the early growth phase is to increase plant reserves at the nursery phase of growth. By adding nutrients to the root plug (nutrient spiking) substrate in the nursery shortly before out planting, rapid and sustained retention of nutrients will occur in the root plug [8].

The nutrient spiking procedure uses a technique where the addition of nutrients is provided immediately before transplanting from the nursery. Seedling root plugs are immersed in nutrient solution to achieve a target ECe level optimal for such planting stock [8]. By providing a readily available source of nutrients to the tree component, crop growth within the agroforestry system may now utilize the native soil nutrients for uptake, thus minimizing the potential for antagonistic interaction between the tree and crop components. Benefits above and beyond reductions in competition may be achieved for a target species through processes other than efficient nutrient cycles, which are not particularly active during initial growing phases. Nutrient spiking techniques will increase fertilizer precision and may reduce the costly and harmful effects of fertilizer over-use [14] and the subsequent negative effects on the local environment. Additionally, with inclusion of perennial trees, C sequestration potential will presumably increase with the overall higher biomass production.

No research to date has examined the use of nutrient spiking in an agroecological context to mitigate tree-crop below ground competition in early growth and in return promote integration and maintenance of trees on farm. Therefore, our research goal is to test the utility of nutrient spiking as an agroforestry technology. We addressed this goal with two research questions: 1) does nutrient spiking provide sufficient internal reserves in the tree stratum to minimize in-situ interspecific nutrient competition? And 2) what are the indirect effects of spiking on target crop growth and nutrition? We hypothesized that nutrient spiking the intercropped tree component will reduce below ground competition with the crop component, consequently increasing crop productivity and nutrition during early growth; higher nutrient reserves in the tree component reduce dependency and stress on native belowground nutrient resources.

The model agroforestry system we chose was corn (Zea maize L.) as the crop stratum and white pine (Pinus strobus L.) as the tree stratum. Although not a common agroforestry system, white pine was selected as a high valued species native to the southern Ontario region with the potential of becoming a highly suitable agroforestry species, thus providing groundwork information on a new temperate system [1]. This study will assist in understanding initial methods for mitigating soil nutrient competition as well as act as a preliminary study on precise nutrient addition techniques to the field of agroforestry. Our approach was to compare monoculture growth and nutrition of individual species with that of intercropped growth and nutrition under spiking conditions. We selected two levels of white pine plug treatment (untreated control and a target level of nutrient spiking) intercropped with corn under greenhouse conditions: control of external conditions, such as light availability, temperature and moisture fluctuations. Vector Competition Analysis [15] and Vector Analysis [16] were employed as appropriate tools for successful evaluation of treatment response.

\section{MATERIALS AND METHODS}

\section{Plant and Soil Material}

Soil used in this greenhouse pot experiment was collected from the Ap horizon (20 cm depth) in a single location in an old-field site at Jokers Hill $\left(44^{\circ} 03^{\prime} \mathrm{N}, 79^{\circ} 29^{\prime} \mathrm{W}\right)$ on the Oak Ridges Moraine in the southern Ontario, Canada. The soil collection site consisted of native and exotic grass species mixture established after agricultural abandonment. These clay loam soils were amended with sand in order to obtain a minimally deficient soil environment within the pots at a ratio of $90 \%$ soil and $10 \%$ sand. Soil total N $(0.18 \%)$ was determined with the Dumas method using a LECO FP428. Soil K (38.2 mg exchangeable $\mathrm{K} \mathrm{kg}^{-1}$ ) was determined with $1.0 \mathrm{~N}$ ammonium acetate extractions and subsequent analysis with atomic absorption spectrophotometry. Soil available $\mathrm{P}$ (30.0 mg available $\mathrm{P} \mathrm{kg}^{-1}$ ) was determined with the Olsen $\mathrm{P}$ method, typical for southern Ontario soils [17]. Soils were characterized by a $\mathrm{pH}$ of 7.8 .

Soil was placed in 16 pots, $30.0 \times 35.5 \times 12.5 \mathrm{~cm}$ in dimension, tapped firmly for settlement and then saturated with distilled water, and allowed to drain for a 24- hour period to reach container capacity, a simulated field capacity in the greenhouse. Uniform one-year old white pine seedlings were obtained from a commercial tree nursery. These seedlings, characterized by approximately $10 \mathrm{~cm}$ long peat plugs, had undergone a hardening phase over winter. Seedlings were planted at a density of 6 seedlings per pot, spaced approximately at $5 \mathrm{~cm}$ apart. Locally supplied corn seeds were similarly spaced and planted at a density of 4 seedlings per pot.

\section{Spiking Trials}

Roots plugs of each white pine seedling were immersed in a nutrient solution, a commercial water-soluble fertilizer (20-20-20 as $\mathrm{N}-\mathrm{P}_{2} \mathrm{O}_{5}-\mathrm{K}_{2} \mathrm{O}$ ). Before soaking, seedlings were not irrigated for three days to ensure sufficient solution uptake. Appropriate solution strength for nutrient spiking was determined from trials using a range of solution strengths $(0 \%, 0.125 \%, 0.25 \%, 0.5 \%, 1.0 \%, 2.0 \%, 3.0 \%$, or $4.0 \%$ in terms of grams of fertilizer per $100 \mathrm{~g}$ of water) ( $\mathrm{n}=9$ seedlings per solution strength). Electrical conductivity measurements were based on saturated aqueous extracts of the peat plug substrate of the test seedlings [18]. Control treatment plugs were immersed in distilled water for the same amount of time before planting in order to ensure consistent moisture content across treatments. Once optimal solution concentration was determined the white pine root plugs were 
immersed in containers of desired solution strengths for 30 minutes. Seedlings were removed from the solution, drained until free water was removed from the root plug and subsequently out-planted with the corn seeds in greenhouse pots. Watering was withheld for three days to ensure minimal leaching of root plug solutions.

\section{Experimental Design}

The experimental design was a complete block design with two levels of white pine plug treatment [untreated (S0) and nutrient spiking (S1)] planted in polyculture and two controls (monocultures of corn $(\mathrm{Cc})$ and white pine $(\mathrm{Cp})$. The treatments were replicated in four blocks. An additive design was employed; the density of individual species remained constant, such that density doubled in the intercropped treatments.

\section{Plant Analysis}

Above and belowground biomass production was measured from destructively sampled corn and pine plants after two months of growth ( $\mathrm{n}=16$ per treatment). Plants were then separated into shoot and root tissue, oven-dried to constant weight $\left(70^{\circ} \mathrm{C}\right.$ for 72 hours) and weighed. Root systems were brushed to remove any remaining soils. Plant nutrient concentration was determined with dry oxidation and analyzed for $\mathrm{P}$ and $\mathrm{K}$ by atomic absorption spectrophotometry. Total $\mathrm{N}$ in plants was determined with the Dumas method using a LECO FP428. Nutrient concentration was multiplied by dry mass [an average of individual plant mass] to determine plant nutrient content.

\section{Statistical Analysis}

Dependent variables of corn and white pine biomass production (shoot and root) and corn nutrient concentration and content were subjected to analysis of variance with four replications using a general linear model (PROC GLM) in SAS version 8.2 (SAS Institute Inc.). In the case of a significant Ftest, treatment means were compared using Tukey's HSD test. Independence, randomness of residuals and a mean error equal to zero were confirmed for biomass, shoot and root nutrient concentration and content and soil nutrient data. Normality of residuals was tested using the Shapiro-Wilk test. A type I error rate was set at 0.05 for all statistical tests.

\section{Vector Analysis}

To evaluate competitive mechanisms involved under nutrient spiking scenarios, we employed Vector Competition Analysis (VCA) and Vector Analysis (VA) diagnostic methods to investigate impacts of interactions on crop and tree production and nutrition [15]. These techniques use bivariate models where vectors depict changing biomass and nutrient status in comparison to a control, a competitive-free state, and allow for simultaneous comparative diagnosis of treatment response.

Based on a regression analysis [19] and vector nutrient diagnosis [16], vector analysis acts as a model for comparing interspecific nutrient interactions in relation to a normalized plant status. Changes in biomass and nutrient uptake are represented as vectors, allowing for comparisons of more than one nutrient and/or spiking level. In this approach, differ- ences associated with plant size and nutrient statuses are eliminated, as changes in biomass and nutrient uptake are expressed in relative terms. Relative values, instead of absolute values, in association with the normalized controls (monoculture $=100$ ), allows for comparisons to be made between multiple trials [20]. To assess nutritional status of corn to treatment effects, we employed VA for a graphical comparison of plant response. Responses were expressed relative to the unfertilized monoculture corn control (that was normalized to 100) to facilitate comparisons between various treatments and nutrients [16, 20, 21].

Vector Competition Analysis is depicted by the crop's response on the vertical axis and tree's response on the horizontal axis. Diagnostic interpretations of relative treatment response are observed as the magnitude and direction of the vectors. This can be an increase $(+)$, decrease (-) or no change $(0)$ in relation to the reference status (respective monocultures of each species). Three shifts in competitive response are possible; synergistic, antagonistic and compensatory [15].

\section{RESULTS}

\section{Spiking Treatment}

To determine optimal spiking percentage, we selected a target electrical conductivity (ECe) of plug substrate solution at $2.0 \mathrm{dS} \cdot \mathrm{m}^{-1}$, the lower level of the range considered desirable for conifer seedling culture [8]. The $1.0 \%$ fertilizer solution strength showed this target ECe in the substrate solution. Hence, we selected a solution concentration of $1.0 \%$ as the optimal nutrient spiking treatment. An average of $21.1 \mathrm{ml}$ of solution was absorbed into the root plug during the $30 \mathrm{~min}$ ute immersion, thus total nutrient uptake under optimal nu-

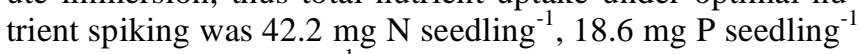
and $35.0 \mathrm{mg} \mathrm{K}$ seedling $^{-1}$ (Table $\mathbf{1}$ ).

Table 1. Substrate Electrical Conductivity, Aqueous Solution Uptake and Nutrient Uptake of Untreated and Optimally Spiked (S1 = 1\%: $1 \mathrm{~g}$ of 20-20-20 per $100 \mathrm{~g}$ of Water) White Pine Root Plugs before Planting (n = 9)

\begin{tabular}{|c|c|c|}
\hline Parameter & Untreated (S0) & Spiked (S1) \\
\hline \hline Electrical conductivity $\left(\mathrm{dS} \mathrm{m}^{-1}\right)$ & 0.2 & 2.0 \\
\hline Solution uptake (average in $\mathrm{ml})$ & 21.1 & 21.1 \\
\hline Nutrient uptake (mg seedling $\left.{ }^{-1}\right)$ & & \\
\hline $\mathrm{N}$ & 0 & 42.2 \\
\hline $\mathrm{P}$ & 0 & 18.6 \\
\hline $\mathrm{K}$ & 0 & 35.0 \\
\hline
\end{tabular}

\section{Growth Response: Spiking and Intercropping Effects}

Corn root biomass $\left(1.93 \mathrm{~g} \mathrm{plant}^{-1} \pm 0.299\right)$ and pine root biomass $\left(1.76 \mathrm{~g} \mathrm{plant}^{-1} \pm 0.156\right)$ response was significantly greater under the nutrient spiking treatment as compared to root biomass production in monoculture (Fig. 1). Corn shoot biomass did not differ significantly between the study treatments (Fig. 1), but overall, corn grown in association with 
(a)

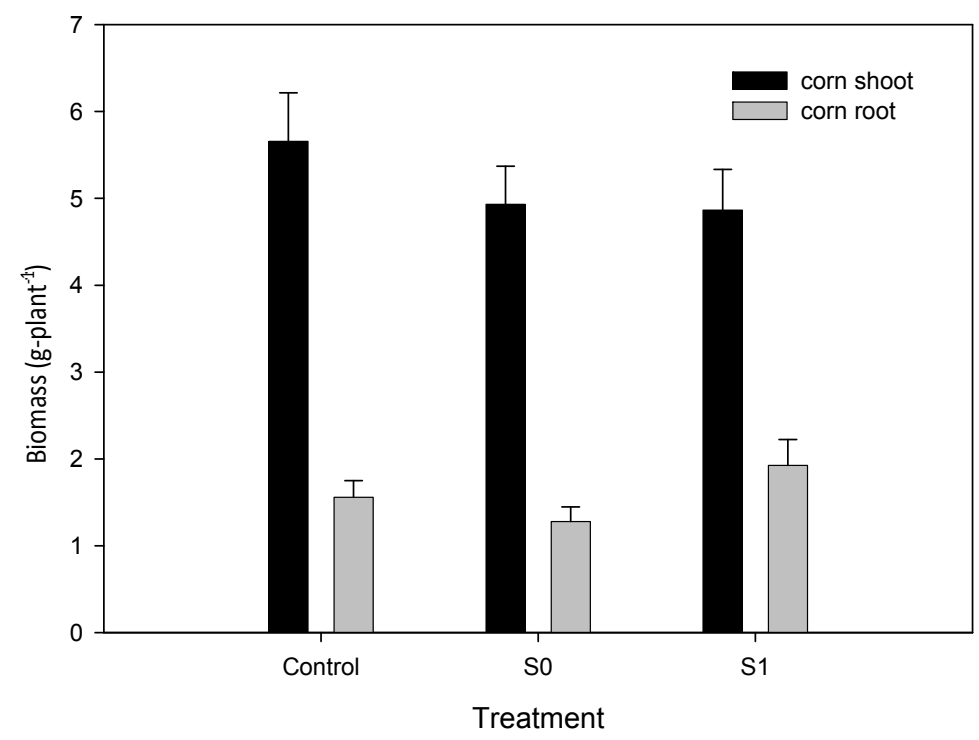

(b)

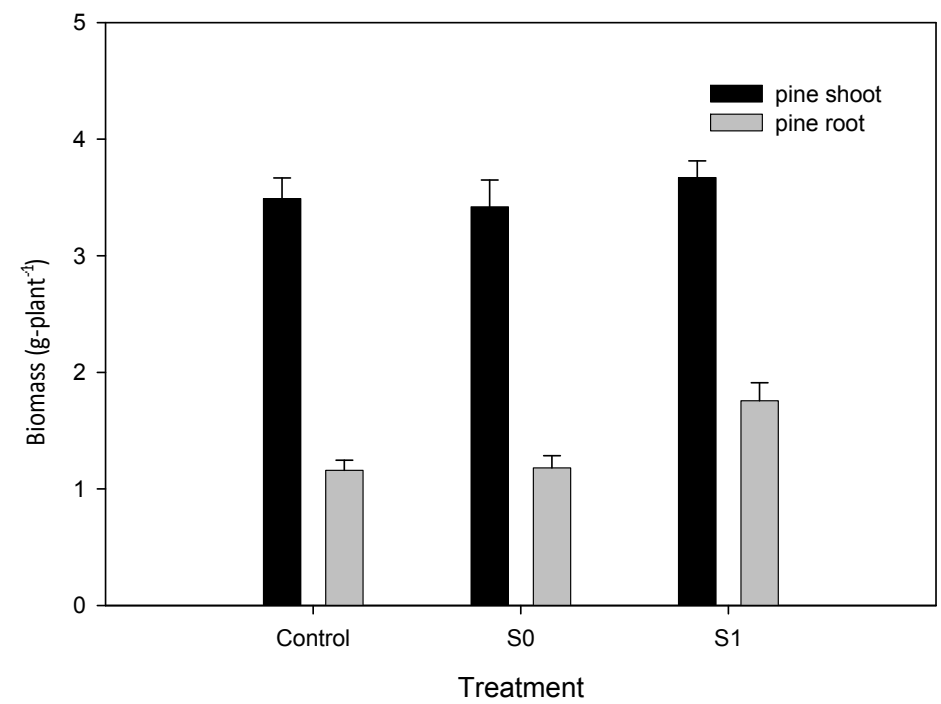

Fig. (1). Shoot and root biomass (g-plant $\left.{ }^{-1}\right)$ in monoculture (control), intercropped with untreated (S0) and with spiking (S1) for a) corn and b) white pine. Bars represent standard errors of the mean $(n=16$ per treatment).

untreated white pine (S0) showed suppressed growth; aboveground biomass of corn declined by $19 \%$ in comparison to monoculture corn growth (Fig. 2). Corn root biomass showed a similar negative intercropping effect and pine root biomass increased by a mere $2 \%$ (Fig $\mathbf{2}$ ).

\section{Nutritional Response}

As expected, shoot $\mathrm{N}, \mathrm{P}$ and $\mathrm{K}$ concentrations in pretransplant spiked pine intercropped with corn revealed significantly higher levels in comparison to no spiking after 2 months of growth (Table 2a). Similarly, N uptake showed significant increases in spiked pine shoot and root tissue as well as significant content levels of $\mathrm{P}$ in shoot and root tissue in comparison to untreated pine in both monoculture and intercropping scenarios (Table $\mathbf{2 a}, \mathbf{b}$ ).

Nitrogen and $\mathrm{P}$ concentration in corn was similar across all treatments in shoot tissue, revealing no treatment effects on plant nutrition. Nutrient concentration levels for all elements in the root biomass showed no difference between treatments, however, were overall lower than concentrations found in aboveground biomass (Table 3a). Similarly, $\mathrm{N}$ and $\mathrm{P}$ uptake in the aboveground corn biomass was, for the most part, similar across treatments for all nutrients such that uptake was comparable to nutrient content found in monoculture corn (Table 3b). In contrast, corn shoot tissue K concentration $(1.46 \pm 0.112 \%)$ and uptake $\left(5.39 \pm 0.414 \mathrm{~g} \mathrm{plant}^{-1}\right)$ was significantly greater in corn associated with spiked white pine in comparison to corn in monoculture.

\section{DISCUSSION}

To reduce agrarian vulnerability to climate change through such functions as hydrological regulation and at the same time increase the carbon storage potential of the agricultural landscape in Canada, new techniques are needed to advance agroforestry in a temperate region context. In order 


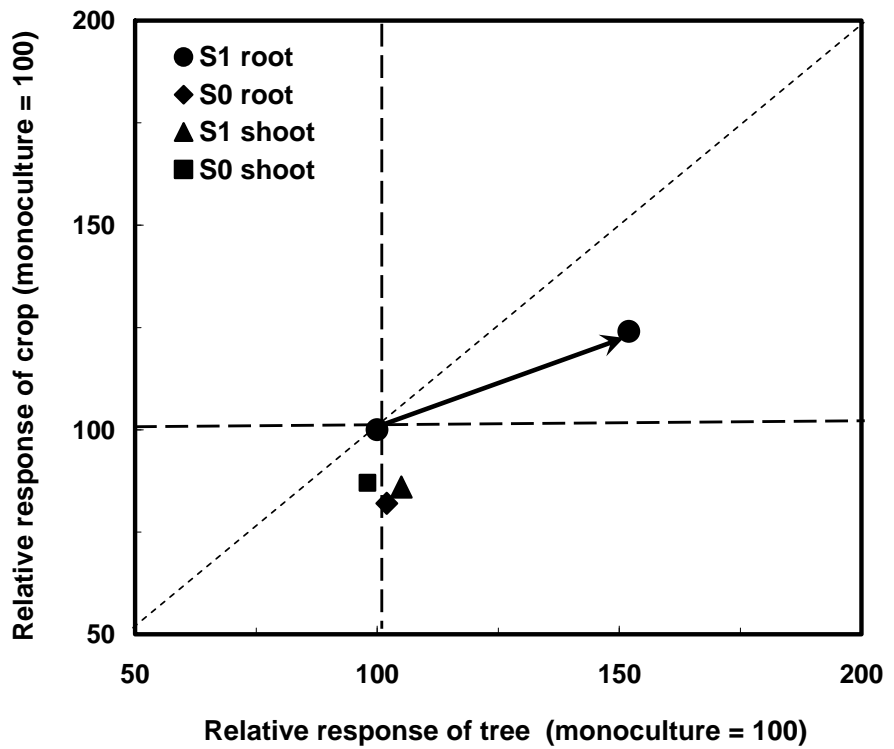

Fig. (2). Vector competition analysis nomogram depicting relative tree (pine) and crop (corn) shoot and root biomass response under intercropping with untreated (S0) and spiked (S1) pine. Biomass response for corn and pine in monoculture was normalized to 100. Vector depicts a significant response (see Imo and Timmer [26]).

Table 2. Mean Nutrient Concentration ( \pm Standard Error) (a) and Content ( \pm Standard Error) (b) in White Pine Shoot and Root Tissue after One Growing Season in Monoculture (Control), with no Spiking (S0) and with Spiking (S1)

(a)

\begin{tabular}{|c|c|c|c|c|}
\hline \multicolumn{5}{|c|}{ Nutrient Concentration (\%) } \\
\hline \multicolumn{5}{|c|}{ Shoot } \\
\hline Treatment & & $\mathrm{N}$ & $P$ & $\mathrm{~K}$ \\
\hline Control & & $2.53 \pm 0.092 \mathrm{ab} *$ & $0.27 \pm 0.010 \mathrm{ab}$ & $1.30 \pm 0.036 \mathrm{ab}$ \\
\hline \multirow[t]{2}{*}{ Spiked } & So & $2.37 \pm 0.006 \mathrm{a}$ & $0.25 \pm 0.008 \mathrm{a}$ & $1.05 \pm 0.012 \mathrm{a}$ \\
\hline & S1 & $2.97 \pm 0.093 b$ & $0.31 \pm 0.011 \mathrm{~b}$ & $1.46 \pm 0.112 \mathrm{~b}$ \\
\hline \multicolumn{5}{|c|}{ Root } \\
\hline Control & & $2.21 \pm 0.135 \mathrm{a}$ & $0.15 \pm 0.020 \mathrm{ab}$ & $0.41 \pm 0.012 \mathrm{a}$ \\
\hline \multirow[t]{2}{*}{ Spiked } & So & $2.10 \pm 0.128 \mathrm{a}$ & $0.16 \pm 0.012 \mathrm{a}$ & $0.35 \pm 0.017 \mathrm{a}$ \\
\hline & $\mathrm{S} 1$ & $2.20 \pm 0.072 \mathrm{a}$ & $0.23 \pm 0.020 \mathrm{~b}$ & $0.32 \pm 0.019 \mathrm{a}$ \\
\hline
\end{tabular}

(b)

Nutrient Content (g Plant $\left.{ }^{-1}\right)$

\begin{tabular}{|c|c|c|c|c|}
\hline \multicolumn{5}{|c|}{ Shoot } \\
\hline Treatment & & $\mathrm{N}$ & $\mathrm{P}$ & K \\
\hline Control & & $8.86 \pm 0.321 \mathrm{a}$ & $0.95 \pm 0.036 \mathrm{a}$ & $4.55 \pm 0.126 \mathrm{ab}$ \\
\hline \multirow[t]{2}{*}{ Spiked } & S0 & $8.06 \pm 0.020 \mathrm{a}$ & $0.86 \pm 0.026 \mathrm{a}$ & $3.58 \pm 0.041 \mathrm{a}$ \\
\hline & $\mathrm{S} 1$ & $11.00 \pm 0.343 b$ & $1.16 \pm 0.042 \mathrm{~b}$ & $5.39 \pm 0.414 \mathrm{~b}$ \\
\hline \multicolumn{5}{|c|}{ Root } \\
\hline Control & & $2.65 \pm 0.163 a$ & $0.18 \pm 0.002 \mathrm{a}$ & $0.49 \pm 0.014 \mathrm{ab}$ \\
\hline \multirow[t]{2}{*}{ Spiked } & So & $2.52 \pm 0.154 \mathrm{a}$ & $0.19 \pm 0.014 \mathrm{a}$ & $0.42 \pm 0.021 \mathrm{a}$ \\
\hline & $\mathrm{S} 1$ & $3.96 \pm 0.130 \mathrm{~b}$ & $0.42 \pm 0.036 \mathrm{~b}$ & $0.57 \pm 0.033 b$ \\
\hline
\end{tabular}

*values followed by the same letter are not significantly different according to a Tukey's HSD test $(\mathrm{p}<0.05)$. 
Table 3. Mean Nutrient Concentration ( \pm Standard Error) (a) and Content ( \pm Standard Error) (b) in Corn Shoot and Root Tissue after One Growing Season in Monoculture (Control), Intercropped with Untreated White Pine (S0) and Intercropped with Spiked White Pine (S1)

(a)

\begin{tabular}{|c|c|c|c|c|}
\hline \multicolumn{5}{|c|}{ Nutrient Concentration (\%) } \\
\hline \hline \multicolumn{5}{|c|}{ Shoot } \\
\hline Treatment & & $\mathrm{N}$ & $\mathrm{P}$ & $\mathrm{K}$ \\
\hline Control & & $2.72 \pm 0.136 \mathrm{a} * 19 \pm 0.029 \mathrm{a}$ & $3.40 \pm 0.327 \mathrm{ab}$ \\
\hline Spiked & $\mathrm{S} 0$ & $2.52 \pm 0.115 \mathrm{a}$ & $0.19 \pm 0.008 \mathrm{a}$ & $3.13 \pm 0.289 \mathrm{a}$ \\
\hline & $\mathrm{S} 1$ & $2.63 \pm 0.086 \mathrm{a}$ & $0.16 \pm 0.015 \mathrm{a}$ & $3.89 \pm 0.449 \mathrm{~b}$ \\
\hline Control & & Root & $0.09 \pm 0.006 \mathrm{a}$ & $0.46 \pm 0.092 \mathrm{a}$ \\
\hline Spiked & & $1.21 \pm 0.123 \mathrm{a}$ & $0.10 \pm 0.007 \mathrm{a}$ & $0.98 \pm 0.342 \mathrm{a}$ \\
\hline (b) & S0 & $1.57 \pm 0.241 \mathrm{a}$ & $0.08 \pm 0.006 \mathrm{a}$ & $0.67 \pm 0.149 \mathrm{a}$ \\
\hline
\end{tabular}

(b)

\begin{tabular}{|c|c|c|c|c|}
\hline \multicolumn{5}{|c|}{ Nutrient Content (g Plant ${ }^{-1}$ ) } \\
\hline \multicolumn{5}{|c|}{ Shoot } \\
\hline Treatment & & $\mathrm{N}$ & $\mathrm{P}$ & K \\
\hline Control & & $1.54 \pm 0.152 \mathrm{a}$ & $0.11 \pm 0.011 \mathrm{a}$ & $1.92 \pm 0.190 \mathrm{a}$ \\
\hline Spiked & So & $1.32 \pm 0.127 \mathrm{a}$ & $0.10 \pm 0.010 \mathrm{a}$ & $1.63 \pm 0.157 \mathrm{a}$ \\
\hline \multicolumn{5}{|c|}{ Root } \\
\hline Control & & $0.19 \pm 0.023 \mathrm{a}$ & $0.01 \pm 0.002 \mathrm{a}$ & $0.07 \pm 0.009 \mathrm{a}$ \\
\hline \multirow[t]{2}{*}{ Spiked } & So & $0.20 \pm 0.026 \mathrm{a}$ & $0.01 \pm 0.002 \mathrm{a}$ & $0.13 \pm 0.017 \mathrm{~b}$ \\
\hline & $\mathrm{S} 1$ & $0.24 \pm 0.037 \mathrm{a}$ & $0.02 \pm 0.002 \mathrm{a}$ & $0.13 \pm 0.020 \mathrm{~b}$ \\
\hline
\end{tabular}

*values followed by the same letter are not significantly different according to a Tukey's HSD test $(\mathrm{p}<0.05)$.

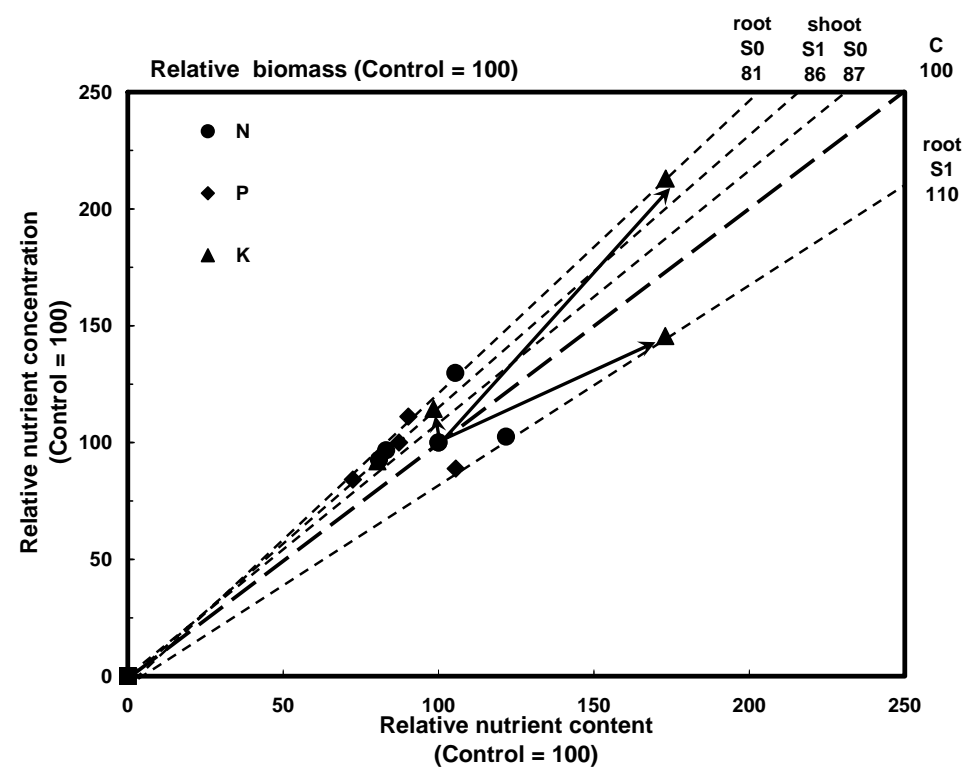

Fig. (3). Nomogram of relative response in dry mass and nutrient content (N, P, and K) of corn shoot and root biomass in monoculture (C), corn intercropped with untreated white pine (S0) and corn intercropped with spiked white pine (S1). Responses are relative to the control: the untreated monoculture corn was normalized to 100. Vectors depict significant responses (see Isaac et al. [21]). 
to promote such integration of trees on the crop landscape, specialized practices may be required to achieve such shifts in complex agricultural management. This study examined the potential for nutrient spiking techniques to mitigate interspecific competition at early growth stages of a white pinecorn intercropping system in southern Ontario. Our results indicate a positive effect of spiking pre-transplant in this model tree-crop system. The spiking effect on corn $(19 \%)$ and pine $(52 \%)$ root biomass when grown concurrently suggests synergistic interactions as interpreted from VCA nomograms. Kasten Dumroese et al. [22] found similar results when studying exponential fertilization of white pine, such that significant effects were pronounced particularly for root growth. We expected some reduction of corn root growth due to an intercropping effect as previous work often points to augmented root competition as a result of asymmetrical root size in early growth $[6,7]$. However, accelerated pine root growth did not suppress corn root biomass and allowed for neutral or even improved conditions for root production of the corn. This suggests that relative increases in corn root biomass intercropped with spiked pine seedlings reflect reduced competition for soil nutrients. It is also possible that some nutrient leaching from spiked pine root plugs also stimulated root growth of corn despite withholding watering for the first three days after planting. However, increased root response under the spiking scenario did not translate into significantly greater aboveground biomass for either species. Although no significant increase was found in aboveground corn biomass intercropped with spiked pine, spiking and intercropping the tree component did not suppress corn production either. These findings are not uncommon as other intercropping studies have found similar responses in temperate agroforestry systems in both field [2] and pot conditions [6].

It is important to note that in our study, antagonistic intercropping effects were mitigated under the nutrient spiked trees, presumably through providing a limiting resource during early growth. As expected, nutrient concentration and content associated with spiking the pine root plug resulted in increased nutrient concentration and content in pine biomass. In general, improved pine nutrition after 2 months of growth illustrated enhanced reserves of $\mathrm{N}, \mathrm{P}$ and $\mathrm{K}$ under spiked conditions. Concurring with previous work on root plug nutrient loading in a forestry context $[12,23]$, a short-term competitive effect for nutrients was alleviated with plug additions.

Corn biomass and nutritional response under the various treatments was simultaneously assessed with vector analysis in an integrated format. Within the vector diagrams, monoculture corn was normalized to 100 to allow for intercropping and spiking treatment response comparisons. Nitrogen and $\mathrm{P}$ uptake in the crop biomass was, for the most part, similar under spiked and untreated trees such that uptake was not significantly different to the nutrition of the crop in monoculture. This response demonstrates $\mathrm{N}$ and $\mathrm{P}$ sufficiency response in so far as nutrient uptake kept pace with growth. In contrast, the $\mathrm{K}$ concentration in corn shoots was significantly greater in association with spiked white pine when compared to corn in monoculture. Such a response indicates a potential excessive consumption of available K. However under the spiking treatment, this significant increase in nutrient concentration levels was matched with a significant increase in biomass $(10 \%$ greater crop root biomass under treated pine in comparison to crop in monoculture). In contrast, no significant increase in corn root biomass was found under untreated pine, indicating luxury uptake of K. Previous studies found similar findings but to a greater magnitude with nutrient spiking; $\mathrm{N}$ and $\mathrm{P}$ concentrations were similar but tended toward higher levels than the control, while $\mathrm{K}$ concentration significantly increased compared to the control [8], which may be due to the mobile nature of potassium.

Increased nutrient uptake suggests a neutral to advantageous effect of spiking on corn biomass and nutrition, particularly in roots. At later stages of corn growth, this result may translate into positive effects on shoot biomass and nutrition through adaptive allocation patterns. Others suggest an internal translocation is regulated by soil nutrient supply and the pool of plant nutrient reserves [23-25] as well as competitive interactions [26], however, further research on internal translocation of nutrients after nutrient spiking is required to assess biophysical responses.

The use of techniques to overcome competition based on initial plant size is of particular importance to successful intercropping. Our findings suggest that following nutrient spiking of tree seedlings, competition, if only temporary, is reduced between the intercropped species. Root biomass significantly increased under the optimal-level spiking treatment for both species. Nutritionally, N, P and K content remained either constant or increased in both species with spiking, suggesting that nutrient uptake kept pace with enhanced growth.

\section{CONCLUSIONS}

For optimal growth of tree and crop components in an agroforestry system, efficient, appropriate and accurate levels of nutrient supplements or external inputs to mitigate competitive imbalances are important to plant health. This study demonstrates the potential of nutrient spiking technique to improve the success of agroforestry practices, particularly in early growth. Although this model system may amplify interactions, as white pine and corn density was high in comparison to appropriate tree spacing in a maturing farm, it does provide preliminary results on initial interspecific interactions. Precise nutrient additions with pre-transplant spiking may be developed to minimize early growth competition, particularly on deficient sites such as marginal or abandoned agricultural land. Although further research is needed on the effects on short-term nutrient additions on internal reserves and the long-term demands on native soil resources, this study demonstrates sound support for future investigation into the utility of nutrient spiking in agroforestry systems.

Secondary benefits to spiking practices are also noteworthy; the reduction in costly and harmful effects of fertilizer over-use at the local scale as well as in $\mathrm{N}_{2} \mathrm{O}$ production at the regional scale remains important drivers for the development of new techniques. By employing nutrient spiking techniques, overall use of fertilizer may be reduced compared to conventional broadcast fertilization. Furthermore, the integration of trees in cropped landscapes results in an important enhancement to carbon sequestration potential; the greater the overall biomass per unit area, such as with the inclusion 
of perennial trees, the greater the potential to store carbon. These aspects are particularly important for marginalized farmland, but also critical for the successful implementation of productive and complex agroecosystems.

\section{ACKNOWLEDGEMENTS}

We would like to thank J. McCarron for assistance. We are grateful to anonymous journal reviewers for helpful and constructive comments on the text. Funding was provided by the Natural Sciences and Engineering Research Council of Canada.

\section{REFERENCES}

[1] Jose S, Gillespie AR, Pallardy SG. Interspecific interactions in temperate agroforestry. Agroforest Systs 2004; 61: 237-55.

[2] Thevathesan NV, Gordon AM. Ecology of tree intercropping systems in the North temperate region: experiences from southern Ontario, Canada. Agroforest Syst 2004; 61: 257-68.

[3] Kimaro AA, Timmer VR, Chamshama SOA, Mugasha AG, Kimaro DA. Differential response to tree fallows in rotational woodlot systems: Post-fallow maize yield, nutrient uptake, and soil nutrients. Agric Ecosyst Environ 2008; 125: 73-83.

[4] Grierson PF, Adams MA. Nutrient cycling and growth in forest ecosystems of south western Australia. In: Lefroy EC, Hobbs RJ, O'Connor MH, Pate JS. Eds. Agriculture as Mimic of Natural Ecosystems. Dordrecht, Netherlands: Kluwer Academic Publishers 1999; pp. 215-44.

[5] Montagnini F, Jordan CF, Machado RM. Nutrient cycling and nutrient use efficiency in agroforestry systems. In: Ashton MS, Montagnini F. Eds. Silvicultural Basis for Agroforestry Systems. Florida, USA: CRC Press LLC 2000; pp. 131-60.

[6] Thevathesan NV, Gordon AM. Moisture and fertility interactions in a potted poplar-barley intercropping. Agroforest Syst 1995; 29: 275-83.

[7] Isaac ME, Ulzen-Appiah F, Timmer VR, Quashie-Sam SJ. Early growth and nutritional response to resource competition in cocoashade intercropped systems. Plant Soil 2007; 298: 243-54.

[8] Timmer VR, Teng Y. Pre-transplant fertilization of containerized Picea mariana seedlings: calibration and bioassay growth response. Can J For Res 2004; 34: 289-98.

[9] Folk RS, Timmer VR, Scarratt JB. Evaluating peat as a growing medium for jack pine seedlings. 1. Conventional quality indices. Can J For Res 1992; 22: 945-9.

[10] Malik V, Timmer VR. Growth, nutrient dynamics and interspecific competition of nutrient loaded black spruce seedlings on a boreal mixedwood site. Can J For Res 1996; 26: 1651-9.
[11] Miller BD, Timmer VR. Nutrient dynamics and carbon partitioning in nutrient loaded Picea mariana (Mill.) B.S.P. seedlings during hardening. Scan J For Res 1997; 12: 122-9.

[12] Idris M, Salifu KF, Timmer VR. Root plug effects on early growth and nutrition of container black spruce seedlings. For Ecol Manage 2004; 195: 399-408.

[13] Burdett AN. Physiological processes in plantation establishment and the development of specification for forest planting stock. Can J For Res 1990; 20: 415-27.

[14] Van Noordwijk M, Cadisch G. Access and excess problems in plant nutrition. Plant Soil 2002; 247: 25-40.

[15] Imo M, Timmer VR. Vector competition analysis of a Leucaenamaize alley cropping system in Western Kenya. For Ecol Manage 2000; 126: 255-68

[16] Timmer VR. Interpretation of seedling analysis and symptoms. In van den Driessche R. Ed. Mineral Nutrition of Conifer seedlings. Inc. Boca Raton, Fla. CRC Press 1991; pp. 113-34.

[17] Carter MR, Ed. Soil Sampling and Methods of Analysis. Canadian Society of Soil Science; 1993, Lewis Publishers

[18] Timmer VR, Parton WJ. Optimum nutrient levels in container growing medium determined by a saturated aqueous extract. Comm Soil Sci Plant Ann1984; 15: 607-18

[19] Goldberg DE. Components of resource competition in plant communities. In Grace JB, Tilman D. Eds. Perspectives on Plant Competition. New York, USA: Academic Press, Inc 1990; pp. 27-49.

[20] Haase DL, Rose R. Vector analysis and its use for interpreting plant nutrient shifts in response to silvicultural treatments. For Sci 1995; 41: 54-66.

[21] Isaac ME, Timmer VR, Quashie-Sam SJ. Shade tree effects in an 8 year-old cocoa agroforestry system: Biomass and nutrient diagnosis of Theobroma cacao by vector analysis. Nutr Cycl Agroecosyst 2007; 78: 155-65.

[22] Kasten DR, Page-Dumroese DS, Salifu KF, Jacobs DF. Exponential fertilization of Pinus monticola seedlings: nutrient uptake efficiency, leaching fractions, and early outplanting performance. Can J For Res 2005; 35: 2961-7.

[23] Xu XJ, Timmer VR. Growth and nitrogen nutrition of Chinese fir seedlings exposed to nutrient loading and fertilization. Plant Soil 1999; 216: 83-91.

[24] Hawkins BJ, Kiiskila SBR, Henry G. Biomass and nutrient allocation in Douglas-fir and Amablis fir seedlings: influence of growth rate and temperature. Tree Physiol 1999; 19: 59-63.

[25] Salifu KF, Timmer VR. Nutrient retranslocation response of Picea mariana to nitrogen supply. Soil Sci Soc Am J 2001; 65: 905-913.

[26] Imo M, Timmer VR. Growth and nutritional interactions of nutrient loaded black spruce seedlings with neighbouring natural vegetation under greenhouse conditions. For Sci 2002; 48: 69-76.

(C) Isaac et al.; Licensee Bentham Open.

This is an open access article licensed under the terms of the Creative Commons Attribution Non-Commercial License (http://creativecommons.org/licenses/ by-nc/3.0/) which permits unrestricted, non-commercial use, distribution and reproduction in any medium, provided the work is properly cited. 